\title{
Implementation of the Blended Learning Method an Accomplishment Way for Learning Outcomes on Training Course at Psychology Department
}

\author{
Lala Septiyani Sembiring $^{{ }^{*}}$, Meria Susanti ${ }^{2}$, Nelia Afriyeni ${ }^{3}$, Izzanil Hidayati ${ }^{4}$, Siska \\ Oktari $^{5}$, Yantri Maputra ${ }^{6}$
}

1,2,3,4,5,6 Psychology Department, Faculty of Medicine, Andalas University

*Corresponding author.Email: lalaseptiyanisembiring@med.unand.ac.id, susanti.meria@gmail.com,

neliaafriyeni@med.unand.ac.id, izzanilhidayati@med.unand.ac.id,siskaoktari@med.unand.ac.id,

yantrimaputra@gmail.com

\begin{abstract}
In optimizing accomplishment for learning outcomes in a subject, it is necessary to do various appropriate method. Especially for courses that have a lot of material content and long study hours, then the blended learning method can be used as an alternative. In this study, the blended learning method was designed and applied in the training course at the Psychology Department, Faculty of Medicine, Andalas University. Evaluation of this course is carried out through a survey on 55 students by giving them a questionnaire. The results indicate that some students have achieved course learning outcomes and consider that the teacher, material and assessment aspects in this course are fit with their expectations.
\end{abstract}

Keywords: blended learning method, Training Course

\section{INTRODUCTION}

The training course is one of the compulsory courses in semester VI at Psychology Department, Faculty of Medicine, Andalas University with 4 credits. The learning outcomes in this course, students are expected to (1) understand the differences about education, training and development, as well as the scope of training in psychological settings, namely Industrial and Organizational Psychology, Social, Educational and Clinical; (2) understanding the learning theory related to the training process; (3) understand the stages of effective training; (4) designing and conducting training; (5) develop soft skills such as being able to cooperate, be confident, show leadership and communicate effectively, discipline, critical thinking, honest and ethical.

In the learning process that took place before, the material was given directly from the lecturer. However, it has been combined with several student-centered methods, namely the student center learning (SCL) method. Kember (1997) suggests that the SCL learning method is an effective learning approach overall. Lea, Stephenson and Troy (2003) say that the principles of learning in the SCL method include that the learner is fully responsible for the learning that they go through, the involvement and participation of students is important in the learning process.

Some of the SCL methods are used, such as presentations, discussions, self-study, and direct application that related to training provision. The lecturer prepares the main materials, then on certain topics students present in the form of presentations and also involve discussion activities. Another learning methodin this course is for students to learn independently. The last method is through direct application, where students carry out training related to predetermined topics. Then, learning achievement in this course is measured through the mid-semester examination, quizzes, individual and group assignments, and the final semester examination. The distribution of final scores in the previous semester is ranging from grades A to B-. These values are influenced by student activity in class, attendance, scores 
on quizzes and assignments, as well as other abilities for each student when carrying out the training.

Based on the learning process that has been carried out, there are various learning outcomes. This is influenced by several things, the first is related to the number of hours ( 4 credits) with a time of 3 hours 30 minutes which is done without a break, frequently making students bored. Second, related to the learning method. Delivering material through lectures, presentations and discussions are methods that commonly used, so that cannot make students more interested in the learning process. Learning methods can be done by methods that can make students more active, for example using certain internet-based platforms (kahoot, zoom, google duo, etc.) followed by games, and role play. By using various methods, it can make students get a new and different learning experience from before, so that the duration of the 4 credits course does not make students fixated on methods that are also used in various other courses.

Regarding student assessments conducted through midterm exams, quizzes, individual and group assignments, and final exams, it can be done by dividing the appropriate percentage. This is done with the consideration that students directly apply the appropriate materials and methods during the training. The training involves students as trainers and the general public (such as students, parents, company employees, etc.) as training participants. This allows students to actively demonstrate their abilities regarding the material or topics raised in the training and has also been presented in the form of modules which also contain independent tasks given to participants during the training process.

Based upon the explanation, the purpose of this study is to find out the description about the achievements of the training psychology course through the blended learning method.

\section{BLENDED LEARNING METHOD}

Efforts to optimize learning outcomes in this training course have carried out several strategies including the following points

\subsection{Revised Syllabus blended learning}

Kember in Gonzalez (2008) states that in general there are two types of learning, namely:

a) Teacher Centered/ content-oriented (TCL). Here there are two roles for the teacher, namely in embed the information and providing structured knowledge.

b) Student Centered/ learning-oriented (SCL). Here there are two roles of the teacher, namely as facilitating understanding and supporting intellectual development
In the previous semester, lecturers delivered material through TCL and SCL using the methods of lecturing, discussion, and doing independent assignments which were carried out face-to-face. This turned out to have drawbacks. One of them, students become less focused when learning activities take place. Giving material through lectures makes students not attached to lectures and not paying full attention. The learning process that is felt to be monotonous for a long time ( 3 hours 30 minutes) makes learning activities less effective. Therefore, improving the learning system through the blended learning system.

Graham in Brown (2016) states that blended learning combines face-to-face and online teaching methods. Blended learning combines face-to-face teaching practice and delivery of material over a distance. Brown (2016) states that there are several aspects to blended learning, namely:

a) Blended learning combines synchronous instruction and asynchronous instruction (Welker \& Berardino in Brown, 2016). Synchronous instruction usually refers to face-to-face learning that is tied to a certain place and time. While asynchronous instruction refers to distance learning activities, where students learn the material independently.

b) Blended learning focuses on combining online media as a learning technology. In this case, digital technology such as social media platforms (facebook, twitter, instragram) or learning management systems can be used in such a way (Koehler \& Mishra in Brown, 2016).

The results showed that students had positive experiences with the blended learning system (Dahlstrom, Walker, \& Dziuban, 2012 in Brown, 2016). The same thing is also shown by the research results of Jesus et al. 2017 in Yen, Lo, Loe, Enriquez (2018) which states that there is a positive relationship between learning outcomes and online learning systems. Honk et al. (2016) in Yen, Lo, Loe, Enriquez (2018) also report a similar thing, where blended learning shows a significance in the high level of knowledge and learning satisfaction compared to face-to-face methods.

Samuelowicz \& Brain (2001) in Gonzalez (2008) found that there are five concepts in teaching, namely supporting student learning, changing student concepts, facilitating understanding, providing knowledge, and embed the information. Meanwhile, Bloom in Santrock (2018) states that there are three learning objectives, namely cognitive, affective, and psychomotor. The cognitive domain consists of 6 objectives, namely:

1. Knowledge, which refers to the ability to remember information 
2. Comprehension, which refers to understanding information and the ability to explain in one's own language

3. Application, which refers to the ability to use knowledge in solving problems in real situations

4. Analysis, which refers to the ability to solve complex information to small pieces of information and to be able to relate various information

5. Synthesis, which refers to combining various information and forming new information.

6. Evaluation, which refers to the ability to make the right decisions

In this course, the final purpose of learning is that students are able to design and make training. If we look at Bloom's taxonomy, the learning objectives go to the evaluation domain. At this stage students are able to make decisions in designing and conducting training according to the needs of the subject. The evaluation at this stage consists of the midterm exam and the training report that has been made.

In general, there are 2 assessments carried out in this course, namely cognitive and soft skills. Both components are assessed throughout the lecture. In general, cognitive assessment is seen from the discussion at each meeting, midterm exam and research proposals and arguments during the proposal exam. Meanwhile, soft skills were assessed from attitudes during class meetings, attendance, how to present training materials, and arguments during guidance or during the proposal exam. The soft skills seen consist of communication skills, logical argumentation skills, cooperation, and time management.

\subsection{Learning Technology Media}

The media technology used in this blended learning system is through the social media platform (whatsapp group, zoom) and the UNAND i-learning website. Social media platforms such as zoom and whatsapp group are used for providing material and discussions related to these materials. Meanwhile, i-learning is to include material (power point), videos that support student understanding and collection of student assignments.

\subsection{Implementation Plan of Blended Learning Syllabus}

The implementation of blended learning syllabus is by combining face-to-face meetings in class and an online system. This method will be applied in the even semester, namely by adding at least 4 teaching materials that will be made in the form of a video. This material is uploaded to the i-learning account so that it can be accessed by students more easily. In this method, it will further maximize the function of the learning account, namely for assigning and collecting assignments, discussions and other features contained in the learning account that support lecture activities. In the form of training design and implementation, the student's final project will also be uploaded via the learning account in video format.

\section{IMPLEMENTATION OF BLENDED LEARNING}

Blended Learning lecture activities on the training course are carried out in the odd semester of 2019/2020 with 4 credits. Blended learning activities carried out in this course combine face-to-face meetings (synchronous instruction) and distance independent learning (asynchronous instruction). At the initial meetings (before midterm exam), most of the learning activities used faceto-face meetings. While the meeting after the midterm exam, learning activities become distance learning activities.

At face-to-face meetings, it is carried out according to the lecture schedule. There are 2 activities carried out in face- to-face lectures, namely explanation of material from the lecturer and discussion. Discussion is conducted to stimulate student activity and help students to be able to understand the lecture material more deeply. In addition, discussion was also conducted to assist students in linking lecture materials with real situations in the field.

Distance learning activities use the i-learn, zoom, and WhatsApp. The use of i-learn media is carried out in uploading videos, assignments, or discussion in lecture activities. There are 4 videos uploaded on the i-learn account. The video contains lecture topics. Students access the video from home and they can watch it at their own time. This is one form of implementation of asynchronous instruction where students carry out the process of independent distance learning. Discussion activities are carried out using discussion forums on ilearn and WhatsApp group discussion.

The final project in this lecture is to make a training video. Students are divided into several groups. They design training modules according to the training design steps that have been delivered in the lecture. In making the assignment, each group has a supervisor. Students consult the training activities that they design with their supervisor. The consultation process is carried out online using Zoom and WhatsApp group. Time for consultation does not have to follow the class meeting schedule, but students are given the flexibility to contact their supervisor.

Lecture activities end at final exam. At that time, students uploaded a training video that they had made through their i-learn account. The lecturer then assesses the video from the aspect of the suitability of the theme with the problems that presented and the form of training 
that made. This assessment activity is also carried out online.

\section{EVALUATION IMPLEMENTATION OF BLENDED LEARNING}

The success of this blended learning method is measured through the suitability of the implementation of the syllabus, namely through several things including an increase in the number of video teaching materials and power point that can be downloaded on ilearning accounts and the output of training designs in various psychological settings, namely organizational, clinical and educational psychology that will be used as an assessment related to learning outcomes accompanied by assessment of student learning processes and outcomes with assessment instruments and rubrics. In addition, a survey was also conducted to obtain feedback from 55 students participating in the lecture regarding the blended learning method being applied.

The survey conducted in general evaluates 2 things, namely (1) evaluation of the achievement of the course learning outcomes, and (2) evaluation of the teaching and learning process (aspects of lecturers, lecture materials and assessment). The scoring ranges for each statement are Strongly Disagree / Agree (1), Disagree / Agree (2), Neutral (3), Appropriate / Agree (4) and Very Appropriate

/ Agree (5). The meaning of scoring is when the student answers according to agree, it can be interpreted that the student really meets the defined criteria.

The evaluation results that obtained based on the average value of each evaluation criteria can be seen in the following table 4.1 .

Table 4.1 Evaluation Value on The Course Learning Outcomes

\begin{tabular}{|c|c|c|c|}
\hline \multirow{2}{*}{$\begin{array}{l}\text { The Course } \\
\text { Learning } \\
\text { Outcomes }\end{array}$} & High & Moderate & Low \\
\hline & \multicolumn{3}{|c|}{ Frequency /Percentage } \\
\hline 1 & $47(84.5 \%)$ & $8(14.5 \%)$ & 0 \\
\hline 2 & $47(84.5 \%)$ & $8(14.5 \%)$ & 0 \\
\hline 3 & $55(100 \%)$ & 0 & 0 \\
\hline 4 & $37(67.3 \%)$ & $18(32.7 \%)$ & 0 \\
\hline 5 & $36(65.5 \%)$ & $18(32.7 \%)$ & $1(1.8 \%)$ \\
\hline 6 & $45(81.8 \%)$ & $9(16.4 \%)$ & $1(1.8 \%)$ \\
\hline 7 & $42(76.4 \%)$ & $12(21.8 \%)$ & $1(1.8 \%)$ \\
\hline
\end{tabular}

On the table, it can be described in more detail regarding the evaluation about the achievement of course learning outcomes, which consists of 7 the course learning outcomes, namely:

1. The course learning outcomes 1 (Understand the differences in education, training and development, as well as the scope of training in organizational industrial psychology, social, educational and clinical psychology settings). Of the 55 students who filled out the survey, out of the 7 statements given. $84.5 \%$ were ini high category and $14.5 \%$ in moderate. This means that for the course learning outcomes 1 , most of the students are compatible with or already understand how difference education, training and development are, as well as the scope of training in organizational industrial psychology, Social, Educational and Clinical psychology settings. So, it can be concluded that the course learning outcomes 1 in this training course has been fulfilled.

2 The course learning outcomes 2 ((Understanding learning theory related to the training process). The survey result of 3 statements in the course learning outcomes 2 shows the same result with first learning outcomes. It means that most of the students have understood the learning theory related to the training process, thus the course learning outcomes 2 in this training course has been fulfilled.

3. The course learning outcomes 3 (Understanding the stages of effective training). Of the 6 statements given, all of students were in high category. This means that they understood the stages of effective training. So that the course learning outcomes 3 in this course has been fulfilled.

4. The course learning outcomes 4 (Designing and conducting training). The result of the 3 statements given $67.3 \%$ were in high category and $32.7 \%$ in moderate. It means that most of students have been able to design and conduct training, so that the course learning outcomes 4 has been fulfilled.

5. The course learning outcomes 5 (Think analytically, critically and creatively and be able to confidently display their abilities). Based on total score of 2 statements there were $65.5 \%$ students were in high category, $32.7 \%$ moderate .Although there is 1 student who feels less able to think analytically, critically and creatively and is able to confidently display his abilities, most of students already have the abilities that are expected to be achieved in this 5th of The course learning outcomes.

6. The course learning outcomes 6 (Cooperate, show leadership and communicate effectively). The results of the answers from 2 statements, it was found that $81.8 \%$ high, but there was 1 student in low category. This means that there are still students who have not been able to work together, show leadership and communicate effectively, even though in general this the course learning outcomes 6 has beenfulfilled.

7. The course learning outcomes 7 (Shows behavior that reflects discipline, politeness, honesty and ethics). Almost similar with $5^{\text {th }}$ outcome, most of students were in high category but there was a student in low category. This means that there are still students who 
have not been able to show behavior that reflects discipline, politeness, honesty, and ethics. But in general, students have met the course learning outcomes 7 in this training course.

Furthermore, the evaluation of the teaching-learning process (aspects of lecturers, lecture material and assessment) can be seen in table 4.2 below

Table 4.2. Evaluation Value on Lecturer, Lecture Material and Asesstment

\begin{tabular}{|c|c|c|c|}
\hline \multirow{2}{*}{ Aspect } & High & Moderate & Low \\
\cline { 2 - 4 } & \multicolumn{2}{|c|}{ Frequency /Percentage } \\
\hline Lecturer & $50(90.1 \%)$ & $5(9.9 \%)$ & 0 \\
\hline $\begin{array}{c}\text { Lecture } \\
\text { Material }\end{array}$ & $29(47.3 \%)$ & $26(52.7 \%)$ & 0 \\
\hline Assessment & $26(52.7 \%)$ & $29(47.3 \%)$ & 0 \\
\hline
\end{tabular}

Based on table 4.2. can be described further regarding student assessment of several aspects, namely:

\section{Lecturer Aspect}

Of the 8 statements submitted, almost of students $(90,1 \%)$ were in high category. This means that mostly agree that the lecturer has a warm and pleasant attitude, has a lecture contract, has the ability and knowledge, prepares learning materials and tools and is willing to help students when they experience problems in lectures.

\section{Lecture Material Aspect}

Based on the 7 statements given, $52.7 \%$ students were in moderate category. This means that more than some students consider this course quite relevant to its objectives, adequate supporting facilities, lectures in the form of discussions and assignments are increase student understanding and find the blended learning system interesting.

\section{Assessment Aspect}

About assessment aspect, more than half of students $(52,7 \%)$ were in high category. This means that students judge that there is transparency and are satisfied with the grades they receive, lecture time is in accordance with the schedule, and there is constructive feedback that students feel.

\section{CONCLUSION}

Based on the implementation and evaluation that has been done, it can be said that the blended learning method is an alternative that can be done in providing material for courses that have a long enough learning duration. The use of technology in the learning process with the blended learning method helps lecturers to deliver teaching materials to students.

The success in implementing the blended learning method can be seen from the results of the evaluation that almost all UNAND psychology students who take the training course can meet and have the abilities specified in the course learning outcomes. Most of the students considered that the lecturer had the characteristics needed in teaching this course, the training course was relevant to its objectives, and the assessment was also clear and transparent.

\section{ACKNOWLEDGMENTS}

This research was carried out with full funding provided from Lembaga Pengembangan Pendidikan dan Penjaminan Mutun (LP3M) of Andalas University. Thus, we thank you for the support that has been given in this research process.

\section{REFERENCES}

[1] Brown, M. G. (2016). Blended instructional practice: A review of the empirical literature on instructors' adoption and use of online tools in face- to-face teaching. Internet andHigher Education 31, 1-10

[2] Direktorat Jenderal Pembelajaran dan Kemahasiswaan Kementerian Riset, Teknologi dan Pendidikan tinggi (2019). Panduan Penyusunan Kurikulum Pendidikan Tinggi di Era Industri 4.0

[3] Gonzalez, C. (2009). Conceptions of, and approaches to, teaching online: a study of lecturers teaching postgraduate distance courses. High Educ, 299-314.

[4] Kember, D. (1997). A reconceptualisation of the research into university academics conceptions of teaching. Learning and Instruction, 7(3), 255-275

[5] Lea, S. J., D. Stephenson, and J. Troy (2003). Higher education students' attitudes to student centred learning: Beyond 'educational bulimia'. Studies in Higher Education, 28(3), 321-334.

[6] Santrock, J. (2018). Educational Psychology. New York: McGraw-Hill Education

[7] Whipp, J. L., \& Lorentz, R. A. (2009). Cognitive and social help giving in online teaching: an exploratory study. Education Tech Research Dev , 169-192

[8] Kurikulum Psikologi FK Unand Tahun 2018 